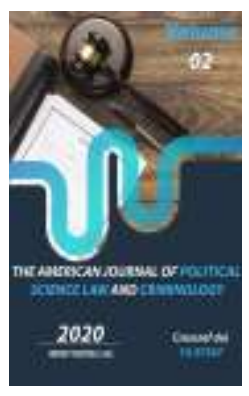

\title{
Types Of Involvement Of Minors In Antisocial Behavior And The Level Of Their Social Danger
}

\author{
Ashurova Nilufar Uktamovna \\ Independent Researcher At The Military Technical Institute Of The National Guard \\ Of The Republic Of Uzbekistan
}

Journal Website:

http://usajournalshub.c

om/index,php/tajpslc

Copyright: Original

content from this work

may be used under the

terms of the creative

commons attributes

4.0 licence.

\section{ABSTRACT}

This article is aimed at strengthening the protection of the rights and freedoms of minors. Particular attention is paid to the study of the trend of adequate criminal protection of the rights and legitimate interests of minors as an object of crime in the world, scientific analysis to improve the mechanisms for ensuring reliable protection of the rights and legitimate interests of minors in achieving socioeconomic stability. In particular, the rights of minors to justice are not fully guaranteed, the issues of improving the legal status of minors in penitentiary institutions are not fully understood, the rights of minors in conflict situations, as well as the socio-economic and political rights of minors, are not fully guaranteed. It is important to examine the implementation of international standards on minors into national legislation. The purpose of the article is to improve the criminal responsibility for involving a minor in antisocial behavior, to identify the causes of this type of crime and to develop specific proposals and recommendations for their elimination.

\section{KEYWORDS}

A minor, a crime, social danger, antisocial behavior, involvement of a minor in antisocial behavior, involving of minor into comment of offence.

\section{INTRODUCTION}

Juvenile delinquency is the future of crime. The fact that 44 percent of the country's population [1] are minors once again demonstrates the relevance of studying criminal law measures to combat the crimes they commit. Any developed democratic state seeks to create good socio-economic conditions for the well-being of its citizens, trying to protect society from such negative phenomena as crime. This is primarily reflected 
in the fight against juvenile delinquency, including by means of criminal law.

As mentioned earlier, the use of physical violence against a minor or intimidation, persuasion, deception, revenge, jealousy, jealousy, psychological influence on a minor by promising to buy or sell something stolen, as well as committing one or more crimes. You can incite to commit a crime by arousing a desire to commit a crime or by reporting the place and methods of committing a crime or the disappearance of its traces.

This means that the involvement of a minor in antisocial behavior can occur in different ways. In general, they were discussed above. It is advisable to divide them into several main methods for further consideration:

- Interest (deception, abuse of trust);

- The use of physical force;

- Intimidation, the use of psychological force (coercion);

- Excitement of evil intentions (revenge, jealousy, envy).

The identification of these methods, the participation of a minor in a crime, a clearer understanding of the motive of the act play an important role in the appointment of a fair punishment. Clause 7 of the Resolution of the Plenum of the Supreme Court of the Republic of Uzbekistan dated September 15, 2000 "On judicial practice in juvenile cases" as it is explained that this information may be important in determining the role of an adult in involving a minor in a criminal or antisocial act [2].

In addition, how the minor was involved in the crime, whether the minor was harmed as a result of these actions, as well as the intensity and severity of the impact on him or her - all this directly affects the level of social risk of committing a crime. There is no doubt that the level of social danger of using a teenager to cheat, steal or coerce, intimidate or turn him into a drug for his own criminal purposes varies.

Juveniles are usually very curious. Human curiosity is emotional in nature and includes: first, sensitivity is an affective state of a person's sensitivity to emotions, movements; secondly, impulsivity is speed, which is embodied as a force that causes such emotions and behavior that strongly affect the human mind; Third, emotional volatility is an emergency that puts an end to a person's emotional state [3].

Deception is the mental and informational impact of one person on the mind and will of another person. Deception is always intended to cause the victim to mentally react to the deception. In particular, the criminal tries not to mislead the deceiving minor, but to direct him into a certain moral channel.

The objective side of deception can manifest itself in action or inaction. Like any act, deception has content and form. The essence of deception is false information about something, an event, an event. The manifestations of deception are diverse in their content, and they can be divided into types. In the legal literature, deception is divided into external, that is, objective and internal (reason, purpose, etc.) factors [4].

Crimes committed with the use of force are understood as crimes in which violence is manifested not only as a way of the objective side of the crime, but also as an integral element of the motive. These include willful homicide, willful infliction of grievous bodily harm, sexual assault, sexual assault and sexual assault. Physical violence is any form of physical contact with a person that causes pain and causes corresponding consequences (throwing from a mountain, kicking, forcibly 
moving a person, forcing him to stay in one place, etc.) [4].

Non-life-threatening violence is defined as beatings, minor injuries, other acts of violence that do not result in short-term disability or disability, and pain or restraint of the victim's will. At the same time, it was emphasized that restriction of freedom should not pose a threat to life and health.

Thus, from the above definitions, it can be understood that the involvement of a minor in physical, non-social or criminal activities through physical violence, in practice, through violence or intimidation with the use of force. Unfortunately, although the level of social risk is higher than with other forms of involvement, these cases are not directly reflected in the law as a separate method of involvement.

One of the most common ways to engage minors in antisocial behavior is intimidation. Bullying is a form of psychological abuse and one of the most common methods of committing a crime. Scientists describe it in different ways, and there are different approaches to its classification. From a theoretical and practical point of view, signs of intimidation are present in a number of criminal law norms, but opinions differ on the necessary legal signs of intimidation, as well as on the relationship between intimidation and psychological abuse.

Intimidation of a minor in the commission of a crime is similar to intimidation in the commission of a crime, except for content such as extortion, rape, etc. This is due to the fact that a person, including a minor, has rights and interests that are protected from harm, life, physical inviolability or, to some extent, secrets that must be kept secret, and the threat of harm arises in every case of intimidation.
Bullying is a form of coercion that affects the psyche of a minor. There are two main methods of such influence: a) influence, consisting in intimidation, causing damage to objects protected by the criminal law; b) direct effect on the unconscious side of the psyche (this may include hypnosis, electronic stimulation of the brain, etc.) [5].

Material dependence is expressed in full or partial financial dependence (dependence, debt) of the subject on the person who forced him to commit a crime.

The above allows us to highlight the main signs of bullying, such as the real likelihood of harm and psychological violence. In the theory of criminal law, several types of intimidation are distinguished: availability of information, accessibility, reality, accuracy, and so on [6]. In our opinion, these are not hallmarks of intimidation.

As noted above, the way in which a juvenile is involved in a crime, regardless of whether he or she suffered moral or physical harm in the process, is not taken into account by the legislature. In our opinion, this is not true, since a teenager can receive serious physical or mental trauma during zero attraction, which is in sharp contrast to the method of deceiving, seducing or other persuasion of a minor. At the same time, an analysis of the criminal law of foreign countries, especially the CIS countries, reveals the following remarkable aspects.

In our opinion, in Article 274 of the Criminal Code it is advisable to qualify the act of involving a minor in the use of narcotic drugs, their analogues or psychotropic substances as an aggravating circumstance. This change makes it possible to differentiate this type of action as follows:

- Responsibility for participation in an administrative offense; 
- Responsibility for recurrence of crimes;

- Liability for participation in a serious or especially serious crime.

Based on the above analysis and the experience of the criminal law of foreign countries, we can say that by differentiating responsibility in the issue under study, it is possible to ensure that responsibility and punishment correspond to the level of guilt and social danger of the individual. Based on this, proceeding from the differentiation criteria analyzed in Article 127 of the Criminal Code of the Republic of Uzbekistan, it is advisable to introduce a sanction of proportionate classification.

In our opinion, how to involve a minor in antisocial behavior should be included in the Criminal Code as a separate norm. Because, firstly, the use of coercion is considered more socially dangerous than other methods that can lead to certain physical or mental harm to a person. In addition, a minor may be subject to physical and psychological suffering and imprisonment by force. Second, defining how participation is carried out can help determine the level of social risk of the crime committed. In our opinion, these proposed additions fill the existing gap and, in practice, law enforcement officers protect the rights and interests of minors, correctly determine their place and status in a crime, as well as accurately and fairly describe the act and give them a fair assessment. allows you to give.

\section{CONCLUSION}

In conclusion, it should be noted that the various ways in which juveniles are involved in antisocial behavior and crimes explored in this paragraph are not the same in terms of the level of social risk, but the differences between them should be noted by the legislature and expressed in criminal law. After all, young people, the next generation are not only the future of the nation, but also the future of peace, tranquility, morality and compassion in society. Adopting minors from a criminal environment is like adopting the future.

\section{REFERENCES}

1. Ismoilov N.T. Individual prevention of juvenile delinquency. PhD dissertation author's abstract for scientific degree. Tashkent .: TDYUI, 2006 .- P. 3

2. Resolution of the Plenum of the Supreme Court of the Republic of Uzbekistan No. 21 dated September 15, 2000 "On judicial practice in cases of minors." with numerical changes and additions // Collection, V.2. - P. 301.

3. Abdurasulova K.R., Zokirova O. A textbook for students of criminology to prepare for exams. - Tashkent, 2003. -P. 17.

4. Piontkovsky A.A., Menshagin V.D. Course of Soviet Criminal Law. The special part. M., 1955.T.1. - P.117.

5. Rustamboev M.Kh. Comments to the Criminal Code of the Republic of Uzbekistan. General section. Tashkent. "ILM ZIYO". 2006. - P. 288.

6. Kruglikov L. Committing a crime under the influence of a threat or coercion, or by virtue of material, service or other dependence. // "Soviet Justice". 1982 ,. No. 9. - P. 26 - 27. 